\title{
Analisis Fitokimia dan Uji Toksisitas Daun Leleng Merah (Graptophyllum pictum (L.) Griffith) dengan Metode Brine Shrimp Lethality Test
}

\author{
Defrikson Ba'u'), Dewa G. Katja ${ }^{1)}$, Vanda S. Kamu'), \\ Paulina V.Y. Yamlean ${ }^{2)}$, Max R.J. Runtuwene ${ }^{\left.1^{*}\right)}$ \\ ${ }^{1)}$ Program Studi Kimia, Fakultas Matematika dan Ilmu Pengetahuan Alam \\ Universitas Sam Ratulangi, Manado \\ ${ }^{2)}$ Program Studi Farmasi, Fakultas Matematika dan Ilmu Pengetahuan Alam \\ Universitas Sam Ratulangi Manado \\ *Corresponding Author: runtuwenemrj@unsrat.ac.id
}

(Article History： Received 12-08-2020; Accepted 10-09-2020; Published 09-10-2020)

\begin{abstract}
ABSTRAK
Penelitian ini bertujuan untuk menentukan total phenolic content (TPC), total flavonoid content (TFC), condensed tannin content (CTC) dan nilai toksisitas dari daun leleng merah. Daun leleng merah diekstraksi dengan metode maserasi dan dipartisi menggunakan pelarut $n$-heksana, etil asetat, dan air. Penentuan nilai TPC menggunakan metode Folin-Ciocalteu. Penentuan nilai TFC menggunakan metode $\mathrm{AlCl}_{3}$. Penentuan nilai CTC menggunakan metode vanillin-HCl. Penentuan nilai toksisitas menggunakan metode BSLT. Nilai TPC yang diperoleh pada fraksi $n$-heksana $(\mathrm{FH})$, fraksi air (FA), dan fraksi etil asetat (FEA) daun Leleng Merah berturut-turut, adalah: 20,48; 31,7; dan 37,57 (mg/g). Nilai TFC diperoleh pada FH, FA, dan FEA berturut-turut, adalah: 0,$64 ; 0,99$; dan 1,27 (mg/g). Nilai CTC diperoleh pada FH, FA, dan FEA berturut-turut, adalah: 0,$56 ; 2,17$; dan $6,52(\mathrm{mg} / \mathrm{g})$. Nilai toksisitas diperoleh pada FEA, FA, FH berturut-turut, adalah: 21,$93 ; 100,7$; dan 117,22 (mg/L). FEA memiliki nilai toksisitas dan kandungan fitokimia tertinggi. Daun leleng merah bersifat toksik.
\end{abstract}

Kata kunci : Brine shrimp lethality test, leleng merah, fitokimia,

\section{Phytochemical Analysis and Toxicity Test of Leleng Merah Leaves (Graptophyllum pictum (L.) Griffith) Using the Brine Shrimp Lethality Test}

\begin{abstract}
This study aims to determine the total phenolic content (TPC), flavonoids (TFC), condensed tannins (CTC) and toxicity value of Leleng Merah leaves. Leleng merah leaves were extracted by maceration method and partitioned using $n$-hexane, ethyl acetate, and water solvent. TPC values were determined using the Folin-Ciocalteu method. TFC values were determined using the $\mathrm{AlCl}_{3}$ method. CTC values were determined using the vanillin- $\mathrm{HCl}$ method. Toxicity values were determined using the BSLT method. TPC values obtained in the $n$-hexane (FH), water (FA), and ethyl acetate (FEA) fraction of the Leleng Merah leaves, were: $20.48 ; 31.7 ; 37.57(\mathrm{mg} / \mathrm{g})$ respectively. TFC values obtained in FH, FA, and FEA, were : $0.64 ; 0.99 ; 1.27(\mathrm{mg} / \mathrm{g})$ respectively. CTC values obtained at FH, FA, FEA, were: $0.56 ; 2.17 ; 6.52(\mathrm{mg} / \mathrm{g})$ respectively. Toxicity values obtained at FEA, FA, FH, were: $21.93 ; 100.7 ; 117.22(\mathrm{mg} / \mathrm{L})$ respectively. FEA has the highest toxicity and phytochemical content. Leleng Merah Leaf is toxic.
\end{abstract}

Keywords : Brine Shrimp Lethality Test, leleng merah, phytochemistry

\section{PENDAHULUAN}

Indonesia merupakan negara kepulauan yang memiliki keanekaragaman hayati yang sangat berlimpah. Salah satunya adalah tumbuhan obat yang tersebar di setiap pulau di Indonesia dengan karakteristik dan khasiatnya yang berbeda-beda. Tanaman obat dalam penggunaannya sebagai pengobatan tradisional adalah alternatif yang dipilih dalam pengobatan karena relatif aman dan 
murah, terapi kanker adalah salah satunya (Pangow et al., 2018).

Ada banyak tanaman obat yang sering ditemukan di daerah Sulawesi Utara diantaranya adalah tumbuhan leleng merah. Tumbuhan leleng merah merupakan salah satu tanaman obat yang bagi masyarakat di daerah pulau Sulawesi. Leleng merah digunakan sebagai obat herbal yang dimanfaatkan sebagai obat sakit kepala dan obat kanker.

Aktivitas antikanker suatu ekstrak sampel ataupun suatu senyawa dapat dideteksi melalui suatu nilai, yang disebut dengan nilai toksisitas (Meyer et al., 1982). Banyak atau sedikitnya kandungan senyawa metabolit sekunder suatu ekstrak tumbuhan obat sangat mempengaruhi nilai toksisitas ekstrak tersebut. Di antaranya adalah fenolik, flavonoid dan tanin (Michałowicz \& Duda, 2007).

Sepengetahuan peneliti belum ada penelitian mengenai tumbuhan leleng merah, termasuk juga pengujian aktivitas sitotoksiknya. Oleh karena itu, peneliti tertarik untuk melakukan penelitian mengenai kandungan total fenolik, flavonoid, dan tanin terkondensasi serta nilai toksisitas daun tanaman leleng merah yang dikenal dengan manfaat antikankernya ini berdasarkan tingkat kepolaran dengan menggunakan pelarut $n$-heksana, etil asetat, dan air. Penelitian ini bertujuan untuk menentukan total phenolic content (TPC), total flavonoid content (TFC), condensed tannin content (CTC) dan nilai toksisitas dari daun leleng merah.

\section{METODE PENELITIAN}

\section{Waktu dan Tempat}

Penelitian ini dilaksanakan selama 2 bulan di Laboratorium Kimia Organik dan Bahan Alam, Jurusan Kimia, Fakultas Matematika dan Ilmu Pengetahuan Alam, Universitas Sam Ratulangi, Manado.

\section{Alat dan Bahan}

Dalam penelitian ini, peralatan yang digunakan adalah blender, ayakan 65 mesh, neraca analitik, tabung reaksi, gelas kimia, kertas saring, erlenmeyer, rotary evaporator, oven, corong pisah, spektrofotometri UV-Vis, vortex. Bahan baku yang digunakan dalam penelitian ini adalah daun leleng merah yang diperoleh dari desa Watuawu, Kabupaten
Poso, Sulawesi Tengah. Bahan yang digunakan adalah pelarut organik teknis seperti: metanol, $n$-heksana, etil asetat, serta bahan lainnya seperti: telur udang Artemia salina serta garam tak beryodium yang diperoleh dari Balai Perikanan Tatelu, Kecamatan Dimembe, Kabupaten Minahasa Utara, Folin Ciocalteu, natrium karbonat, aluminium klorida heksahidrat, kuersetin, vanilin, asam klorida pekat, katekin, asam galat, aquades, dan vaselin.

\section{Preparasi Sampel}

Sampel daun Leleng merah dibersihkan lalu dikering-anginkan selama seminggu. Setelah sampel kering, sampel diblender sampai menjadi serbuk kemudian diayak dengan ayakan (65 mesh). Sebanyak 1000 g simplisia dimaserasi selama $3 \times 24$ jam menggunakan pelarut metanol. Setelah itu, disaring hingga diperoleh filtrat. Filtrat yang diperoleh kemudian dievaporasi, dikeringkan didalam oven pada suhu $40^{\circ} \mathrm{C}$ hingga diperoleh ekstrak pekat. Sebanyak 15 g ekstrak pekat (hasil maserasi) dilarutkan dalam $100 \mathrm{~mL}$ aquades. Kemudian larutan dipartisi dengan menambahkan $n$-heksana (50 $\mathrm{mL}$ ) ke dalam corong pisah, lalu dikocok dan didiamkan hingga terdapat dua lapisan. Lapisan yang terbentuk kemudian dipisahkan, lapisan $n$-heksana diambil. Penambahan pelarut $n$-heksana dalam aquades diulangi hingga $n$-heksana menjadi bening. Dengan cara yang sama, lapisan aquades kemudian dipartisi kembali menggunakan pelarut etil asetat,. Hasil partisi dievaporasi hingga diperoleh fraksi disetiap pelarut.

\section{Penentuan Total Phenolic Content (TPC)}

Penentuan TPC dilakukan dengan menggunakan prosedur yang dikembangkan oleh Conde et al. (1997). Sebanyak, 0,1 mL larutan ekstrak $(10.000 \mathrm{mg} / \mathrm{L}$ yang dibuat dengan melarutkan $0.05 \mathrm{mg}$ ekstrak dengan pelarut aquades $5 \mathrm{~mL}$ ) dimasukkan ke dalam tabung reaksi, kemudian ditambahkan $0,1 \mathrm{~mL}$ Folin Ciocalteu 50\%, lalu divortex, $2 \mathrm{~mL}$ larutan $\mathrm{Na}_{2} \mathrm{CO}_{3} \quad 2 \%$ ditambahkan dan divortex. Setelah itu, selama 30 menit campuran diinkubasi dalam ruangan gelap. Absorbansi dibaca pada panjang gelombang $750 \mathrm{~nm}$ menggunakan spektrofotometer. Kurva kalibrasi dipersiapkan, dengan menggunakan asam galat sebagai standar. 
TPC dinyatakan sebagai $\mathrm{mg}$ ekivalen asam galat/g ekstrak.

\section{Penentuan Total Flavonoid Content (TFC)}

Penentuan TFC dilakukan dengan mengikuti prosedur Meda et al. (2005). Sebanyak, $1 \mathrm{~mL}$ larutan ekstrak (10.000 $\mathrm{mg} / \mathrm{L}$ yang dibuat dengan melarutkan 0.05 $\mathrm{mg}$ ekstrak dengan pelarut aquades $5 \mathrm{~mL}$ ) dimasukkan ke dalam tabung reaksi. Setelah itu, ditambahkan $2 \mathrm{~mL} \mathrm{AlCl} \mathrm{Al}_{3} \%$ (dalam metanol), lalu divortex. Absorbansi ekstrak dibaca pada panjang gelombang $415 \mathrm{~nm}$ dengan menggunakan spektrofotometer. Kurva kalibrasi dipersiapkan, dengan menggunakan kuersetin sebagai standar. TFC dinyatakan sebagai mg ekivalen kuesertin/g ekstrak.

\section{Penentuan Condensed Tannin Content (CTC)}

Penentuan CTC dilakukan mengikuti prosedur Julkunen-Tiitto (1985), Sebanyak, $0,1 \mathrm{~mL}$ larutan sampel dimasukkan ke dalam tabung reaksi yang dibungkus aluminium foil. Selanjutnya, $2 \mathrm{~mL}$ larutan vanillin $(4 \%$ dalam metanol) ditambahkan dan divortex. Setelah itu, $1 \mathrm{~mL} \mathrm{HCl}$ pekat ditambahkan dan divortex lagi. Setelah campuran diinkubasi selama 20 menit pada suhu kamar, absorbansi sampel dibaca pada panjang gelombang 319 $\mathrm{nm}$. Kurva kalibrasi dipersiapkan, dengan menggunakan katekin sebagai standar. CTC dinyatakan sebagai ekivalen katekin dalam mg/g ekstrak.

\section{Uji Toksisitas}

Berdasarkan prosedur Mayer et al. (1982), sebanyak 10 ekor larva udang $A$. salina yang berumur 48 jam dimasukkan ke dalam wadah yang berisi $100 \mathrm{~mL}$ larutan ekstrak dengan konsentrasi 62,$5 ; 125 ; 250$; dan 500 ppm. Dilakukan 2 kali pengulangan untuk setiap konsentrasi ekstrak dan dibandingkan dengan larutan air garam dengan konsentrasi $20 \mathrm{~g} / \mathrm{L}$ sebagai kontrol. Pengamatan dilakukan selama 24 jam dengan interval waktu 6 jam.

Perhitungan kematian udang Artemia salina dihitung sesuai dengan rumus berikut:

$$
\% \text { Mort }=\frac{\text { Jumlah larva yang mati }}{\text { Jumlah larva uji }} \times 100 \%
$$

Apabila pada kontrol ada udang yang mati, prosentase kematian udang A. Salina ditentukan dengan rumus Abbot's, sebagai berikut:

$$
\begin{aligned}
& \frac{\% \text { Mort }=}{\% \text { kematian (uji)-\%kematian (kontrol) }} \\
& 100-\% \text { kematian pada kontrol } \\
& 100 \%
\end{aligned}
$$

Hasil yang diperoleh dinyatakan sebagai nilai $\mathrm{LC}_{50}$ sampel uji, yaitu jumlah konsentrasi sampel uji yang dapat menyebabkan kematian larva udang sejumlah $50 \%$ setelah masa inkubasi 24 jam, yang dihitung menggunakan persamaan regresi dengan menghubungkan pengaruh konsentrasi sampel (logaritma nilai konsentrasi) terhadap persen mortalitas larva uji yang dikonversi dalam nilai probit.

\section{Analisis Data}

Analisis data untuk menentukan nilai kandungan total fenolik, total flavonoid, dan total tanin terkondensasi menggunakan analisis regresi pada software microsoft office excel untuk menghasilkan gambar grafik yang maksimal dan software statistik lainnya untuk penentuan nilai toksisitas.

\section{HASIL DAN PEMBAHASAN}

\section{Ekstraksi Maserasi dan Partisi}

Hasil rendemen yang didapat dari ekstraksi daun Leleng Merah yaitu 12,55 \%. Hasil partisi yang diperoleh dapat dilihat dalam Tabel 1.

Tabel 1. Rendemen Hasil Partisi Daun Leleng Merah

\begin{tabular}{cc}
\hline Hasil Partisi & Rendemen (\%) \\
\hline$n$-heksana & 12,67 \\
Air & 44,87 \\
Etil Asetat & 4,47 \\
\hline
\end{tabular}

Berdasarkan Tabel 1, hasil rendemen tertinggi adalah pada fraksi air kemudian diikuti fraksi $n$-heksana dan etil asetat. Tingginya rendemen fraksi air disebabkan banyaknya jumlah senyawa polar yang terkandung dalam daun Leleng Merah dibandingkan dengan 2 fraksi lainnya. Beberapa senyawa metabolit sekunder yang larut dalam air (bersifat polar) antara lain adalah fenolik, flavonoid dan juga tanin. Penggunaan pelarut dengan tingkat kepolaran 
yang berbeda akan mempengaruhi jenis senyawa yang terekstrak.

\section{Penentuan Total Phenolic Content (TPC)}

Hasil TPC fraksi $n$-heksana, etil asetat dan air daun Leleng Merah dapat dilihat pada Gambar 1.

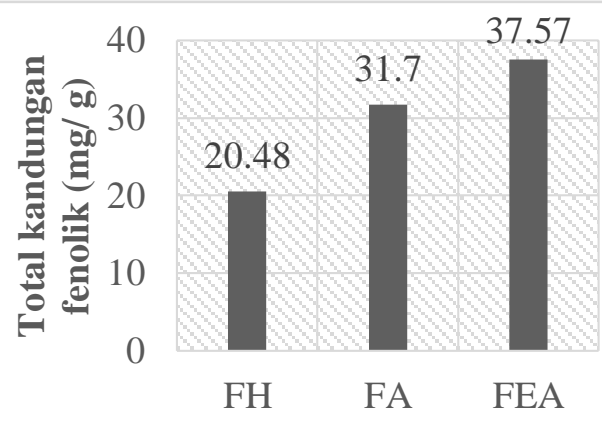

Gambar 1. Total Phenolic Content (FH= fraksi $n$-heksana; FEA= fraksi etil asetat; dan FA= fraksi air)

Berdasarkan grafik pada gambar 1, nilai TPC tertinggi diperoleh dari fraksi etil asetat sebesar $37,57 \mathrm{mg} / \mathrm{g}$. Hal ini menunjukkan bahwa pada fraksi etil asetat daun Leleng Merah terdapat banyak senyawa fitokimia jenis fenolik yang aktif dibandingkan dengan fraksi yang lainnya. Rohman et al. (2006), melaporkan bahwa untuk mengektraksi senyawa fenolik pelarut etil asetat sangat cocok, banyak senyawa fenolik alami mengandung sedikitnya satu gugus hidroksil dan membentuk senyawa eter, ester atau glikosida yang lebih banyak daripada senyawa bebasnya. Hasil penelitian ini mendukung laporan tersebut.

Uji TPC dengan metode FolinCiocalteu pada dasarnya bertujuan untuk mengetahui kandungan fenol yang terdapat dalam fraksi $n$-heksana, etil asetat dan air daun Leleng Merah. Metode ini didasari oleh adanya kemampuan fraksi daun Leleng merah untuk mereduksi Folin-Ciocalteu berwarna kuning yang mengandung senyawa fosfomolibdat dan asam fosfotungstat menjadi senyawa kompleks molibdenumtungstat yang berwarna biru (JulkunenTiitto, 1985).

\section{Penentuan Total Flavonoid Content (TFC)}

Hasil TFC fraksi $n$-heksana, etil asetat dan air daun Leleng Merah dapat dilihat pada Gambar 2.

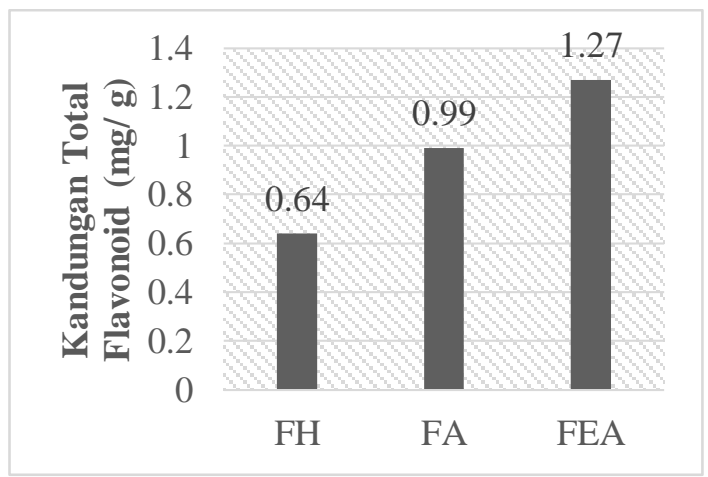

Gambar 2. Total Flavonoid Content $(\mathrm{FH}=$ fraksi $n$-heksana; FEA= fraksi etil asetat; dan $\mathrm{FA}=$ fraksi Air)

Berdasarkan grafik pada gambar 2, nilai TFC tertinggi diperoleh dari fraksi etil asetat sebesar $1,27 \mathrm{mg} / \mathrm{g}$. Hal ini menunjukkan bahwa pada fraksi etil asetat daun leleng merah terdapat banyak senyawa fitokimia jenis flavonoid yang aktif dibandingkan dengan fraksi yang lainnya. Manik et al. (2014), melaporkan bahwa aktivitas flavonoid tertinggi ditemukan pada fraksi etil asetat suatu ekstrak, hal ini disebabkan karena aglikon yang kurang polar seperti isoflavon, flavanon, flavon, memiliki kecenderungan untuk mudah larut dalam pelarut etil asetat dan hasil dari penelitian ini mendukung laporan tersebut. Pada pengukuran kadar flavonoid, penggunaan $\mathrm{AlCl}_{3}$ dikarenakan senyawa flavonoid dapat bereaksi dengan logam $\mathrm{Al}^{3+}$ pada gugus hidroksi, keton, dan orto-dihidroksi yang membentuk senyawa kompleks berwarna kuning. Semakin pekat warna kuning yang dihasilkan maka semakin tinggi konsentrasi flavonoid tersebut (Sultana et al., 2014).

\section{Penentuan Condensed Tannin Content (CTC)}

Hasil CTC fraksi $n$-heksana, etil asetat dan air daun Leleng Merah dapat dilihat pada Gambar 3. Berdasarkan grafik pada gambar 3, hasil yang diperoleh diketahui bahwa CTC tertinggi adalah pada fraksi etil asetat sebesar $6,52 \mathrm{mg} / \mathrm{g}$. Hal ini menunjukkan bahwa pada fraksi etil asetat daun Leleng Merah terdapat banyak senyawa fitokimia jenis tanin terkondensasi yang aktif dibandingkan dengan fraksi yang lainnya. Rosamah et al. (2017), melaporkan bahwa fraksi yang larut dalam etil asetat, kaya dengan kandungan tanin terkondensasi dan hasil penelitian ini mendukung laporan tersebut. Prinsip pengujian menggunakan vanilin- $\mathrm{HCl}$ dalam 
penentuan CTC adalah vanilin terprotonasi dalam asam, menghasilkan karbokation yang bereaksi dengan flavonoid. Senyawa antara hasil reaksi tersebut mengalami dehidrasi yang menghasilkan senyawa berwarna ungu atau merah (Rambi et al., 2016).

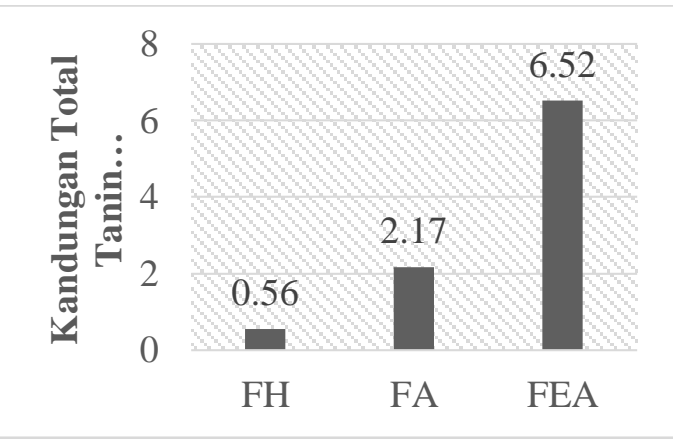

Gambar 3. Condensed Tannin Content $(\mathrm{FH}=$ fraksi $n$-heksana; FEA= fraksi etil asetat; dan FA= fraksi air)

Uji Toksisitas (Brine Shrimp Lethality Test)

Nilai toksisitas $\mathrm{LC}_{50}$ hasil partisi daun Leleng Merah dapat dilihat pada Tabel 2.

Tabel 2. Nilai Toksisitas $\mathrm{LC}_{50}$ dari Hasil Partisi Daun Leleng Merah

\begin{tabular}{cc}
\hline Ekstrak Sampel & $\begin{array}{c}\text { Nilai Toksisitas } \\
\mathrm{LC}_{50}(\mathrm{mg} / \mathrm{L})\end{array}$ \\
\hline Etil asetat & 21,93 \\
Air & 100,7 \\
$n$-Heksana & 117,22 \\
\hline
\end{tabular}

Berdasarkan Tabel 2, aktifitas sitotoksik tertinggi diperoleh pada fraksi etil asetat sebesar 21,93 mg/L. Hal ini disebabkan karena kandungan senyawa fenolik, flavonoid dan tanin terkondensasi tertinggi terdapat pada fraksi etil asetat daun Leleng Merah. Meyer et al. (1982), mengemukakan bahwa suatu senyawa atau pun ekstrak dapat dikatakan toksik apabila memiliki nilai toksisitas yang dinyatakan dengan nilai $\mathrm{LC}_{50}$ sebesar < 1000 ppm, maka daun Leleng Merah pada seluruh varian fraksi dapat dikatakan toksik.

Semakin tinggi kandungan metabolit sekundernya hal ini berupa senyawa fenolik, flavonoid dan tanin terkondensasi, maka semakin besar pula nilai toksisitasnya. Dalam hal ini, besarnya sumbangsih kadar fenolik, flavonoid dan tanin terkondensasi pada fraksi etil asetat daun Leleng Merah menjadi faktor yang mempengaruhi tingginya nilai toksiksitas.

Adanya senyawa flavonoid, fenolik, dan tanin dalam sel dapat menyebabkan pecahnya membran sel. Hal ini disebabkan karena gugus $\mathrm{OH}$ pada flavonoid, fenolik, dan tanin berikatan dengan protein integral membran sehingga transpor aktif $\mathrm{Na}^{+}$dan $\mathrm{K}^{+}$ terhenti. Transpor aktif yang terhenti menyebabkan pemasukan ion $\mathrm{Na}^{+}$dan $\mathrm{K}^{+}$ tidak terkendali dalam sel, yang menyebabkan pecahnya membran sel Membran sel yang pecah dapat menyebabkan kematian pada sel (Scheuer, 1994).

Selain itu, flavonoid telah terbukti menyebabkan apoptosis (kematian sel) pada beberapa biakan sel kanker, sedangkan sel-sel normal diselamatkan (Ren et al., 2003). Fenol dan turunannya diketahui dapat menyebabkan aktivitas apoptosis yang dimediasi protein caspase dan sitotoksisitas pada berbagai biakan sel kanker (Nandi et al., 2007). Tanin diketahui dapat menyebabkan aktivitas apoptosis yang dimediasi asam tanat pada biakan sel kanker (Yildirim \& Kutlu, 2015). Mekanisme apoptosis sel dalam hal ini adalah karena fragmentasi DNA. Fragmentasi ini dimulai dengan rantai proksimal DNA yang disebut AIF (Apoptosis Inducing Factor), yaitu protein yang memicu kondensasi kromatin dan fragmentasi DNA dalam sel untuk memicu kematian sel terprogram, yang lepas oleh senyawa oksigen reaktif, contohnya radikal hidroksil (Dencic et al., 2012).

\section{KESIMPULAN}

Kandungan total fenolik dari partisi $n$ heksana, etil asetat, dan air secara berturutturut adalah 20,48; 31,7; dan 37,57 (mg/g). Kandungan total flavonoid dari partisi $n$ heksana, etil asetat, dan air secara berturutturut adalah 0,$64 ; 0,99$; dan 1,27 (mg/g). Kandungan total tanin terkondensasi dari partisi $n$-heksana, etil asetat, dan air secara berturut-turut adalah 0,$56 ; 2,17$; dan 6,52 $(\mathrm{mg} / \mathrm{g})$. Kandungan total fenolik, flavonoid, dan tanin tertinggi adalah partisi dengan pelarut etil asetat. Nilai toksisitas partisi ekstrak daun Leleng Merah dari fraksi pelarut etil asetat, air dan $n$-heksana secara berturutturut adalah 21,93; 100,7; dan 117,22 (mg/L). Nilai toksisitas tertinggi diperoleh pada fraksi 
pelarut etil asetat dibandingkan dengan fraksi pelarut lainnya.

\section{DAFTAR PUSTAKA}

Conde, E.F., M.C. Cadahia, B.F.D. GarciaVallejo, J.R.G. Adrabos \& Simon. 1997. Low Molecular Weight Polyphenols in Cork of Quercus Suber. Journal Agricultural and Food Chemistry, 45(7): 2695-2700.

Dencic, M.S., J. Poljarevic \& U. Vilimanovich. 2012. Cyclohexyl Analogues of Ethylenediamine Dipropanoic Acid Induce CaspaseIndependent Mitochondrial Apoptosis in Human Leukemic Cells. Chemical Research in Toxicology, 25(4): 31-39.

Julkunen-Tiitto, R. $1985 . \quad$ Phenolic Constituents in Leaves of Northern Willows: Methods for The Analysis of Certain Phenolics. Journal of Agricultural and Food Chemistry, 33(2): 213-217.

Manik, D.F., T. Hertiani \& H. Anshory. 2014. Analisis Korelasi Antara Kadar Flavonoid dengan Aktivitas Antibakteri Ekstrak Etanol dan FraksiFraksi Daun Kersen (Muntingia calabura L.) Terhadap Staphylococcus aureus. Khazanah, 6(2):1-11.

Meda, A., C.E. Lamein, M. Romito, J. Milliogo \& O.G. Nacoulina. 2005. Determination of the Total Phenolic, Flavonoid and Proline Content in Burkina Fasan Honey, As Well As Their Radical Scavenging Activity. Journal of Food Chemistry, 91(1): 571-577.

Meyer, B.N., N.R. Ferrigni, J.E. Putnam, L. B. Jacobsen, D.E. Nichols \& J.E. McLaughlin. 1982. Brine Shrimp: A Convenient General Bioassay for Active Plant Constituents. Planta Medica, 45(5): 31-34.

Michałowicz, J. \& W. Duda. 2007. Phenols Sources and Toxicity. Polish Journal of Environment Study, 16(3): 347-362.

Nandi, S., M. Vracko \& M.C. Bagchi. 2007. Anticancer Activity of Selected Phenolic Compounds: QSAR Studies Using Ridge Regression and Neural Networks. Chem Biol Drug. 70(5): 424-43.
Pangow, M.E., W. Bodhi \& E. de Queljoe. 2018. Skrining Fitokimia dan Uji Toksisitas dari Ekstrak Etanol Daun Manggis (Garcinia mangostana L.) dengan Metode Brine Shrimp Lethality Test (BSLT). Pharmacon, 7(3): 97107.

Rambi, G.A.D., V.S. Kamu \& M.R.J. Runtuwene. 2016. Uji Fitokimia dan Antioksidan dari Daun Yantan (Blumea chinensis DC). Jurnal MIPA UNSRAT Online, 5(1): 32-35.

Ren, W., Q. Zhenhua, W. Hongwei, Z. Lei \& Z. Lie. 2003. Flavonoid: Promising Anticancer Agents. Department of Hematology, $2^{\text {nd }}$ Hospital of Shanxi Medical University, Taiyuan.

Rohman, A., S. Riyanto \& D. Utari. 2006. Antioxidant Activities, Total Phenolic and Flavonoid Contents of Ethyl Acetate Extract of Mengkudu (Morinda citrifolia, L) Fruit and Its Fractions. Majalah Farmasi Indonesia, 17(3): 136-142.

Rosamah, E., H.M.R. Awaliyan \& E. Sukaton. 2017. Karakteristik Tanin dari Ekstrak Kulit Kayu Leda (Eucalyptus deglupta Blume.). Jurnal Hutan Tropis, 1(1): 16-28.

Scheuer, J.S. 1994. Produk Alami Lautan. IKIP Semarang Press, Semarang.

Sultana, N., A.R. Alimon, K.S. Haque, A.Q. Sazili, H. Yaakub \& S.M.J Hossain. 2014. The Effect of Cutting Interval on Yield and Nutrient Composition of Different Plant Fractions of Moringa Oleifera Tree. Journal Food and Agricultural Environment, 12(2): 599604.

Yildirim, I. \& T. Kutlu. 2015. Anticancer Agents: Saponin and Tannin. International Journal of Biological Chemistry, 9(6): 332-340. 